\title{
A QUESTIONNAIRE ON MARKETS
}

\author{
By John W. Farley, \\ Chairman of Committee on Investigation of Municipal Markets, \\ Memphis, Tenn.
}

Memphis is superior to other cities for assembling raw material for manufacturing and equal in facilities for distributing manufactured products. These advantages and facilities, however, are secondary to labor. If this city is to compete with manufacturers in other cities, the cost of labor must be reduced to a minimum.

The best development of Memphis, as of any city, is also dependent upon increasing the prosperity of the surrounding agricultural communities, thereby increasing their purchasing power. With our already excellent system of good roads, producers could easily reach the proper market place if wise facilities and regulations were established.

The question was raised whether both these ends could not be furthered through municipal markets. To study this question a special committee was appointed by the Commission Government of Memphis. ${ }^{\text {In }}$ order to get together the facts as to the results obtained by markets in other cities, and as to the proper regulations and facilities for such markets, should Memphis decide to adnpt a market policy, the following questions were sent to the dozen cities indicated. These questions and their answers are submitted here for the use of administrative officials who may have similar queries in other cities, and for their value to all students of the market problem.

1 The other members of the committee are: Charles E. Brower and John L. Parham. Because of its exceptional value to those interested in furthering or developing markets, those pages of this committee's report dealing with the answers to the questions sent out by them are reprinted here. It is regretted that the entire report cannot be published. The part published here is, the editors believe, of significant value to all who have practical market problems to solve, and to all students of direct marketing.-The Editor.

139 


\section{Name of city and population and name of official giving information.}

Baltimore, Md. : population 558,489; Jas. H. Thrift, comptroller.

Cincinnati, Ohio: population, 540,000; Theo. Braken, superintendent public lands and buildings.

New Orleans, La. : population, 360,000; Alex. Pujol, commissioner of public buildings.

San Antonio, Texas : population, 105,000; J. H. Parker, city market master.

Seattle, Wash. : population, 254,000; J. E. Crichton, commissioner of health.

Norfolk, Va. : population, 81,524; Wm. Hanna, chairman board of control.

Boston, Mass.: population, 675,000; Geo. E. McKay, superintendent of markets.

Montreal, Canada: population, 600,$000 ;$ J. E. A. Biron, superintendent of markets.

Rochester, N.Y.: population, 235,000; Edwin A. Fisher, city engineer.

Indianapolis, Ind.: population, 275,000 ; Jno. B. Wood, secretary board of public safety.

Columbus, Ohio: population, 200,000; Chas. E. Reinhard, superintendent of markets.

Dubuque, Ia.: population, 40,000; F. A. Gniffke, ex-city treasurer.

\section{How long has your market been established?}

Baltimore: Established before incorporation of city. Ground bought in 1804; stalls rented by the year in 1811. Cincinnati: 1850 . New Orleans: As old as the city. San Antonio: 12 years present market, but have had a city market 150 years. Seattle: 5 years. Norfolk: Present location a little over 20 years; prior to that a market was established many years ago on large public square leading to ferry connecting this city with the city of Portsmouth, maintained for many years. Boston: Two buildings separated by a street eighty feet wide; both buildings known as Faneuil Hall Markets; smaller building erected in 1742, gift from Peter Faneuil. In 1826, the larger building known as Quincy Market was opened. The smaller closed and not reopened until 1857, when more room was necessary. Montreal: At present there are five meat and provision markets, one of which is known as the Bonsecours Market, established in 1845. Rochester: Since June 1, 1905. Indianapolis: Since beginning of city. Columbus: 62 years. Dubuque: Between 75 and 80 years. The time of its beginning is rather indefinite.

\section{Does the city own or lease the market places?}

Markets are municipally owned in all these cities.

\section{How many market places in your city?}

Baltimore: 11 retail and 1 wholesale fish and 1 wholesale produce. Cincinnati: Four. New Orleans: Thirty-three. San Antonio: One general mar- 
ket place. Seattle: Two. Norfolk: One controlled by the eity. Boston: One public market place and perhaps 2,000 places where meats and provisions are sold. Montreal: Five meat and provision markets as well as one hay and two cattle markets. Rochester: One. Indianapolis: One. Columbus: Four. Dubuque: One.

\section{How is the market controlled?}

Baltimore: By the city comptroller, power vested in him by the ordinances of the mayor and city council, giving him right to collect rents and licenses. Cincinnati: Superintendent, chief market master, assistant market masters and watchmen. New Orleans: Inspectors. San Antonio: Market master under mayor. Seattle: Department of health and sanitation. Norfolk: Superintendent of markets under rules and regulations prescribed by the board of control. Boston: Ordinance. Rochester: Market commission. Indianapolis: City ordinance and under the board of public safety. Columbus: Director of public service and superintendent of markets. Dubuque: Market master who receives $\$ 65$ a month.

\section{What is the value of the property used for the market?}

Baltimore: All the markets over $\$ 1,000,000$. New Orleans: Hard to approximate. San Antonio: $\$ 100,000$. Seattle: Value not given. Norfolk: Land and buildings $\$ 358,000$. Boston: For taxable purposes and establishing rents, $\$ 1,800,000$. Montreal: $\$ 570,000$. Rochester: $\$ 191,000$. Indianapolis: About $\$ 1,000,000$. Columbus: About $\$ 300,000$. Dubuque: About $\$ 10,000$.

\section{What is the cost of operation?}

Baltimore: About $\$ 20,000$, exclusive of repairs. Cincinnati: About $\$ 12,000$, but we get this back and make some more from the licenses. New Orleans: $\$ 9,000$ per year. San Antonio: About $\$ 600$ per month. Seattle: $\$ 265$ per month. Norfolk: $\$ 2,920$ per year. Boston: About $\$ 12,000$, not including repairs. Montreal: Cost of operation, including repairs will amount this year (1912) to $\$ 35,665$. Rochester: For the year 1911, $\$ 6,172.01$. Indianapolis: About $\$ 15,000$ yearly. Revenue about $\$ 35,000$. Columbus: About $\$ 21,000$. Dubuque: Practically nothing. While the market master draws a salary, he serves as janitor of City Hall, one of the city's weighmasters and city jailer. The fees from stand owners pay for cleaning up after market hours.

\section{What are the sources of revenue by which the market is supported?}

Baltimore: Per diem receipts, rentals and licenses, varying according to the markets. Cincinnati: Licenses from people having stands in the markets. New Orleans: Daily fees from stall keepers for use of stalls. San Antonio: Rents in market building and rents from plazas (two squares) on outside, also fees for inspection of animals slaughtered. Seattle: 10 cents a day for stalls or tables. Norfolk: Rents collected for stalls and spaces. For year ending June 30, 1912, total of rent $\$ 17,129.55$. Boston: Rentals. Montreal: Rents 
total for $1911, \$ 66,556.57$. Rochester: Leasing of the stands. Indianapolis: Leasing of stands. Columbus: Rental of stalls and stands, and hall rent in market houses. Dubuque: The only revenue is the fee for the stands, total of about $\$ 430$.

\section{Do you have a building with stalls?}

Baltimore: All are covered and have stalls. Cincinnati: We have 4 buildings with stalls, also outside market. New Orleans: Yes. San Antonio: Yes. Seattle: Yes. Norfolk: Yes. Boston: Yes. Montreal : Each of the markets is provided with inside butcher's stalls, and outside stalls around same occupied by fruit and vegetable traders only. Rochester: 228 stalls are covered with a roof. Indianapolis: Yes. Columbus: Yes. Dubuque: Yes, but abandoned it for this use 30 years or more ago.

10. If so, to whom are they rented, $i$. e., are they rented to producers or to persons who are simply merchants?

Baltimore: Both. Cincinnati: Inside are butchers, cheese and butter men; outside all kinds of venders. New Orleans: Small merchants. San Antonio: Merchants and butchers. Seattle: To those who have a right under city and state laws to sell. Norfolk: Not to producers to any extent, chiefly to merchants or hucksters. Boston: Rented to merchants. Montreal: Parties known as traders only. Rochester: Rented to producers and hucksters. Indianapolis: Both. Columbus: Producers and dealers in meats, fruits and vegetables. Dubuque: Mostly to producers, a few to simply merchants.

\section{What is the average number of stalls rented?}

Baltimore: About 5,500 stalls. Cincinnatì: All the market house stalls are rented always. New Orleans: Approximately 700. San Antonio: Inside 40 ; outside 75 . Seattle: 200 at the most, usually 125 to 135 . Norfolk: Stalls in butchers' market are much in demand and seldom vacant; in vegetable market 144 stalls and average number rented is 130. Boston: 132 stalls in the larger market and 44 basements, all occupied by tenants on a ten-year lease. Montreal: The number of stalls depends entirely on size of each market. Rochester: All-about 600. Indianapolis: About 675 inside; about 300 outside. Columbus: 690 stands and stalls. Dubuque: By the city about 50 . In addition to this by private property owners on busy days (curbstone space) probably 500 .

12. What is the average number of wagons in the market from which produce is sold on market days?

Baltimore: Perhaps 1,500. New Orleans: Vary greatly. San Antonio: About 75. Norfolk: On Saturdays 60 to 75; on other days varying from 1 or 2 up to 25 . Boston: 300 to 450 wagon loads busy days; on almost any day dullest part of year from 75 to 150 loads. Montreal: As high as 1,500 in one 
market day at Bonsecours Market (the most extensive). Rochester: Busy season (peach) 1,200 loads every day; average 300 per day. Indianapolis: Average 150. Columbus: About 300, average 100. Dubuque: From 30 to possibly 600 .

13. Are producers permitted to sell from wagons in the market? If so, on what terms?

Baltimore: Yes. Spaces rented for $\$ 5$ annually. Cincinnati: No. Unless they have a license, then they have to unhitch and stable their horses. San Antonio: 10 cents per day or $\$ 2.50$ per month. Seattle: No. Norfolk: Yes. They are required to pay 10 cents per day for single wagon; 15 cents for double. Boston: Producers sell wholly from their wagons. Montreal: Producers have only the right to sell from wagons at public market. Market fees on each are inserted in Article V, Section 48, By-Law No. 296, concerning markets. Rochester: Yes. Without extra payment. Indianapolis: No. Only outside. Columbus: No. Dubuque: All is practically sold from wagons by producers. No restrictions except payment of fee for occupying curbstone space and the universal rule that his wares must be wholesome, sanitary and come up to his representations and of legal weight and measure.

14. What is the average number of miles producers haul their produce to sell it in the market?

Baltimore: 8 to 10 miles. Cincinnati: About 15. New Orleans: 5 miles. San Antonio: About 6. Most of products are from gardens close in. Seattle: $7 \frac{1}{2}$ miles. Norfolk: Approximately 12 miles. Boston: There are on our roll some 1,200 farmers; some come only once or twice a year, others for two or three weeks. Many come for certain days in the week for six or seven months in year. Montreal: Between 8 and 25 miles. Rochester: 5 to 6 . Indianapolis: 5 or 10. Columbus: About 25 miles. Dubuque: Some come 40 miles. Probably 15 might be fair average.

15. What do they do with the produce remaining unsold when the market closes for the day?

Baltimore: Take it back home or sell or give to the poor. Cincinnati: Sell to commission houses near market. New Orleans: Just enough is brought by each wagon as experience shows will be sold. San Antonio: Perishables are placed in refrigerators. Seattle: Taken back to their gardens outside city limits. Norfolk: If any considerable quantity, it is sold to commission houses. Boston: The farmers usually come from radius of 30 miles; occupy space in streets around market and adjoining streets when necessary; no charge is made for this; they remain all day and over night into following day if necessary to dispose of their produce; if necessary to go home before they dispose of everything, they leave it with commission merchants to dispose of. Montreal: Produce remaining unsold is taken back home. Rochester: Take it home or peddle it in the streets. Indianapolis: Sell it to commission men. Colum- 
bus: Take it home or sell it to some grocer. Dubuque: Keep reducing the price for bargain hunters. The commission houses and shippers and grocers usually take the surplus. The city absorbs nearly all.

16. Are the articles offered for sale inspected before sale by an official of the city?

Baltimore: Health department inspectors visit daily. Cincinnati: No. New Orleans: Yes. San Antonio: Yes. By meat inspectors and market master. Norfolk: Food inspector is always on duty to attend inspection of food products. Boston: The superintendent of markets and officials under him supervise all produce offered for sale and nothing allowed to be sold which is unfit for food. Montreal: No. But if found by the clerks of market during sale, unfit for consumption, or if attention is called by consumers, produce is immediately seized. Rochester: Yes. Indianapolis: Yes. By Board of Health officers. Columbus: Yes. Dubuque: Market master, police, state food inspectors are at all times, of ten in unexpected quarters, looking for violations of pure food laws. Convictions speedy, fines heavy.

17. What is the approximate value of produce sold on an average market day?

Baltimore: Hard to estimate; 50,000 people visit Lexington Market on Saturdays. Cincinnati: No way of telling. New Orleans: Impossible to say. San Antonio: About \$1,400. Seattle: Do not know. Norfolk: Impossible to answer. Boston: Unable to say. Montreal: Approximate value of produce in each wagon estimated between $\$ 35$ and $\$ 40$. Rochester: Cannot say. Indianapolis: About $\$ 20,000$. Columbus: About $\$ 20,000$. Dubuque: Extremes would vary between $\$ 150$ and $\$ 8,000$. The latter may be too low.

18. What is the average number of people who buy in the market on market days?

Baltimore: About 50,000 visit the markets. At least 25,000 buy. Cincinnati: 25,000 on ordinary days; 60,000 Saturday. New Orleans: Impossible to say. San Antonio: About 500. Seattle: Many thousands. Norfolk: On Saturdays probably 7,000 or 8,000 . Boston: No means of knowing but would be reckoned by thousands. Montreal: Two classes of buyers, consumers purchasing at retail and proprietors of butcher stalls and grocers purchasing wholesale. Calculated by hundreds. Rochester: It is a wholesale market but about 300 people per day buy in the market. Indianapolis: On Saturdays it is always packed the whole day. Columbus: About 20,000. Dubuque: Impossible to approximate. Probably 3,500 .

\section{What classes of people buy in the market?}

With the exception of Cincinnati and San Antonio the markets are frequented by all classes. In those cities the working class especially uses the market. 


\section{What is the attitude of the general consuming public towards the market?}

Baltimore: Decidedly favorable. Cincinnati: A great benefit. New Orleans: Favorable. San Antonio:Favorable. Seattle: Very favorable. Norfolk: Very favorable. Boston: Generally very favorable. Montreal: Generally speaking, the public appreciate the markets, for their advantage is found in variety of produce offered for sale as well as in cost of same, which is less than what is asked for in shops, stores, etc., outside of the public markets. Rochester: Take very little interest in it. Indianapolis: Approval and favor. Columbus: Favorable. Dubuque: Great loyalty.

\section{Is the use of the market by the consumer increasing or de- creasing?}

Baltimore: Bad weather is to blame for any decrease. Cincinnati: Difficult to find out. New Orleans: Stand-still. San Antonio: Increasing. Seattle: About stationary. Has brought about better conditions among groceries in city. Norfolk: Gradually increasing. Boston: Normal. Some retail trade scattered by reason of residents moving from market districts to remote sections of city and suburbs where they obtain supplies from local dealers, who by use of order carts and telephone can be supplied immediately no matter how small the order. Montreal: Population increasing and buyers increasing proportionally. Rochester, Indianapolis, Columbus, Dubuque: Increasing.

22. What effect does the market have on the general scale of prices of food in your city in the way of reducing prices?

Baltimore: Scale of prices is somewhat lower in the markets. Cincinnati: Reduces cost to people that pay cash but has no effect on credit buyers. New Orleans: Difference of opinion on that subject. San Antonio: Reduces prices as producer and consumer meet in the market. Seattle: Tendency to reduce prices in everything except meat. Norfolk: Prevents raising of prices by grocery stores by facilitating operation of the general law of supply and demand. Boston: Cannot say that it has any unless consumer buy from producer by the box or barrel. Nothing sold in market but best grades of meats and provisions, and price of this quality is cheaper than in local markets. Montreal: Buyers generally pay less at markets than in shops, stores, etc. Rochester: No appreciable effect. Indianapolis: Can be bought cheaper and fresher at market. Columbus: It keeps grocers and other dealers in produce and fruits in check from taking advantage and boosting prices. Dubuque: Keeps prices down very materially.

23. Is the producer using the market to sell his produce more or less than formerly?

Baltimore: More. Cinncinati: More volume of business but might be due to increased population. New Orleans: Producers sell to stall keepers 
largely. San Antonio: More. Seattle: More. Norfolk: Slightly more than formerly. Boston: Number of producers not materially changed. Montreal: There are no other ways for producers to sell their produce on the markets; they may, however, consign to commission merchants. Rochester: More. Indianapolis: More. Columbus: Some less. Dubuque: More.

24. Do you consider the market a very potent factor in keeping down the cost of living in your city?

Baltimore: Yes. Cincinnati: Yes. New Orleans: No. San Antonio: Somewhat. Seattle: It undoubtedly assists in lowering cost of living. Our markets are not large enough to have a very appreciable effect. Norfolk: Yes. Boston: See answer to 22. Montreal: Yes, by fact that the producer can offer his produce for sale direct to consumer, avoiding then every possible understanding which may exist between merchants respecting sale prices. Rochester: No. Indianapolis: Yes. Columbus: Yes. Dubuque: It undoubtedly is.

\section{What is the average distance people will walk to buy in the market?}

Baltimore: They don't have to do much walking; trolley cars pass each of the 11 markets and the 11 markets are scattered about city, serving all sections. Cincinnati : All car lines transfer to market and people will come at least 1 mile on foot to market. San Antonio: About 6 blocks. Seattle: Not more than a half mile. This is a very hilly city and the nickel is our smallest money. Norfolk: Market is centrally located and people come from all parts of city, and even from outside city limits to deal in the market. Boston: Unable to say as our people are inclined to use public conveyances. all of which come close to market district. Montreal: The markets being scattered about the city, the distance to walk to reach them is slight. Rochester: $1 \frac{1}{2}$ miles. Indianapol is: All over the city. Columbus: Markets can be reached by street cars but some will walk from 7 to 10 blocks. Dubuque: Compactly built city. More people to the square mile than any other city in the state. Nineteen blocks at farthest will take you among the producers.

\section{How many people depend on the market for supplying their daily needs?}

Baltimore: See answers to 17 and 18. More people on Saturday than other days. Groceries are not sold in markets, so the public must always depend on grocers. Cincinnati: No way of telling. New Orleans: Almost the population. San Antonio: Probably 3,000. Seattle: Impossible to state. Norfolk: Difficult to estimate; probably 10,000. Boston: Have no means of knowing; a large number. Montreal: About half of population. Rochester: Wholesale market about 300 . Indianapolis: Very few families in our city who do not attend market at least one day in the week. Columbus: 75,000. Dubuque: Practically entire city. The grocers keep vegetables but they must meet 
gardeners' and farmers' competition because they must buy in the same market and sell at same prices. Their profits come from buying larger quantities and giving their merchandise in barter for farm products.

\section{Is the number decreasing or increasing?}

Baltimore, Cincinnati, San Antonio, Norfolk, Montreal, Rochester, Indianapolis, Columbus and Dubuque: Increasing. Seattle and Boston: Normal.

28. How far is your principal market place from the center of the business district?

Baltimore: We have 11 markets; one, Lexington Market, is in heart of city shopping district. Cincinnati: Four squares. San Antonio: $\frac{1}{2}$ mile. Seattle: Three blocks. Norfolk: It is in the center. Boston: In center of business district, surrounded by provision stores for radius of mile. Montreal: Principal market, Bonsecours Market, is situated in center of business district. Rochester: 1 miles. Indianapolis: Within 2 blocks and directly opposite County Court House. Columbus: 2 blocks. Dubuque: Between 3 and 6 blocks.

29. What is the attitude of the commission merchant toward the retail market?

Baltimore: Of course the commission merchant for his owa selfish interests would do away with anything that interferes with his profits but our markets were established before the commission merchant opened up his business. Cincinnati: They have stands in it and use it as an outlet for their perishable goods. New Orleans: Favorable. San Antonio: Friendly. Seattle: No outward evidence of antagonism at this time. It must injure their business, however. Norfolk: Favorable to the market. Boston: Favorable. Montreal: They are in no way connected with markets. Rochester: Veryfriendly. Indianapolis: Does not meet with their approval. Columbus: Very amicable. Dubuque: Suppressed hostility. They view it as an evil that must be endured. It gives them a good place to buy for outside orders.

\section{What is the attitude of the huckster toward the market?}

Baltimore: See 29. Cincinnati: Same as commission merchants. New Orleans: Unfavorable. San Antonio: Friendly, as they do most of their buying at market. Seattle: Rather antagonistic. Norfolk: The renter of vegetable market stalls is called a huckster. Your question probably refers to what we call a peddler, $i$. e., a man who buys his goods from commission houses and peddles them through the streets. Of course, the latter is opposed to the market. Boston: Favorable as at a time of a surplus of provisions he purchases at low prices which enables him to dispose of same at a profit. Montreal: Their only business connection with the market consists of buying their necessary supplies which they subsequently sell throughout the city. Rochester: 
Unfriendly. Indianapolis: Favorable. Columbus: The country huckster is the one that stands on the market and the city huckster is not very favorable to the market. Dubuque: It is his paradise. He has his stands here.

\section{Is the huckster permitted to peddle during the hours the market is open}

Baltimore: Not within prescribed limits. Cincinnati: Not in the market unless he has a license and then he must unhitch his horses and remain in one place. San Antonio: Not within 6 blocks. Seattle: Yes. Norfolk: Peddler is probably intended here. The peddler is not restricted as to hours. Boston: He is permitted to sell anywhere in the city if he has a license (except in the market limits). No person is permitted to occupy space allotted to the farmers unless he is a producer. Montreal: Yes. Rochester: Any time after 8 a.m. Indianapolis: Yes. Columbus: The huckster is permitted to sell his produce at a stand on the market providing he pays stand rent. Dubuque: Yes, he is, but the peddling huckster is an almost unknown person in Dubuque.

32. What is the attitude of the corner grocer towards the market?

Baltimore: See 29. Cincinnati: They all market every day. New Orleans: Hostile. San Antonio: Friendly. Scattle: They seem to believe it is an infringement on their business prerogative. Boston: The same as would be toward any one carrying on business in competition. Montreal: They buy at the markets all the farm produce they require for the necessary supply to their customers. Rochester: Not very friendly. Indianapolis: Decidedly against it. Columbus: Not very favorable. Dubuque: The grocer looks on it as a great wrong to the business man who has rent to pay, etc.

33. What are the principal criticisms of your market and by whom made?

Baltimore: Perhaps the necessity of providing new building and general improvements desired by the public and the market people. Cincinnati: Some people that own property in place dedicated to market purposes do not like the noise. Some venders do not like to pay license. New Orleans: Political. San Antonio: Do not know of any unfriendly criticisms as market has been in operation 150 years. Seattle: That it is not really a cheaper place in which to buy produce; that the men selling take undue advantage of purchaser, and in the rush work off less wholesome food. Norfolk: The vegetable market is a frame building, and there is a general feeling that a building of better construction should be provided. Boston: So far as its size is concerned, opinion of persons visiting from other states, foreign countries and people of our own city, is that it is the best conducted market they have ever seen. Montreal: The only inconvenience the public have to complain of concerning the principal market, which is the Bonsecours market, is that the space reserved for the farmers and the public as well, is too exiguous. Rochester: By grocers, because market gardeners sell at retail. Indianapolis: Only from those under-sold. 
Columbus: When they get short weight or measure or when they buy goods that are represented as first class and prove not to be so. Dubuque: There are no criticisms. This is a broad statement but true. Grocers and commission men have a grievance but no criticism.

\section{Is there a general cold storage plant operated in connection} with the market?

Baltimore, Cincinnati, San Antonio, Seattle, Norfolk, Rochester, Dubuque, Columbus: No plant. New Orleans: In one market, yes. Boston: We are supplied with brine cold storage which is conducted through pipes to the market from a building about an eighth of a mile distant. Montreal: Refrigerating system is now in course of installation for the use of all the tenants of the Bonsecours Market. Indianapolis: In the meat market, yes.

\section{Would you advise the establishment of one?}

Baltimore: Have never considered it. Would never advocate it under control of municipality as this should be a private rather than a public enterprise and to establish one here would be in competition with existing corporations. Cincinnati: Certainly do. New Orleans: Yes. San Antonio: Yes. Seattle: It would depend on the financial status of the city, the wholesomeness of goods sold in the grocery stores, and the profits grocerymen are making. Norfolk: Yes. Boston: Yes. Montreal: Yes. Rochester: Yes. Indianapolis: We know it is a success and if closed would raise a great howl. Columbus: Yes. Dubuque: Yes, wherever possible.

36. What are the best features about your market from the consumer's standpoint?

Baltimore: Fresh goods, low prices. Cincinnati: Fresh goods and cheaper but cash prices. New Orleans: That best food is obtained at a minimum. San Antonio: Consumer meets producer and has a good market to select from. Seattle: Nearness to business center and to big truck gardens. The control over food products by law by health department. Norfolk: It regulates the prices charged by stores. Rochester: It furnishes an opportunity for the producers to bring their produce to one place and deal with the consumer either directly or through grocers. Columbus: The consumer's standpoint is that he has a larger and greater variety to select from. Dubuque: The consumer and producer have a free and unrestricted market to buy and sell.

37. What are the best features about your market from the producer's standpoint?

Baltimore: Quick sales, ready money. Cincinnati: Sells more at a smaller price but gets cash. San Antonio: Producer meets consumer with resulting elimination of middleman. Seattle: Nearness to business center and big truck 
gardens. Norfolk: It is of great assistance to him in disposing of his produce. Montreal: See 36. Rochester: See 36. Columbus: From the producer's standpoint, he gets a better price than he would receive from the grocer or commission merchant as the middleman's profit is divided between consumer and producer. Dubuque: See 36 .

38. If you were establishing a market in your city, what are some of the most important features you would incorporate into it?

Baltimore: We would seriously consider the question of open or closed market. Cincinnati: Have the space clearly defined; the class of people allowed to peddle free of charge, defined; collect rents in advance; pick a wide street so there would be no blocking of traffic; see that it is kept in a sanitary condition. New Orleans: Cold storage plant throughly screened-cleanlinesswith small daily fees to be dedicated to repairs of markets. San Antonio: Cleanliness, plenty of room, cheap rents, and conducted so as to be just selfsustaining. Seattle: Nearness to the greatest number of people; proper sanitary arrangements of stalls, buildings; properly paved and drained streets; properly lighted, with unusual abundance of water for all purposes and a proper ordinance giving authority for control and to make rules and regulations. Norfolk: The system as it has existed in Norfolk has proven very satisfactory, but the butchers' market should be equipped with cold storage plant. Boston: Should construct it on same plan, give more space to each stall and provide cold storage in the building to supply each tenant; would enforce the regulations to the letter and spirit; allow no influential dealer to have the ear of some person on the board of management; would select as superintendent a person known to be thoroughly competent for the position; pay him a salary sufficient to justify him in having no friends to whom he might show favoritism, and if making a ruling in accordance with the regulations support him in carrying out such ruling no matter who might feel aggrieved. Rochester: No reason for any change from the present market. Dubuque: Our market practically is unrestricted. Three-quarters of a century of training of producers, sellers and buyers have made it self-regulating, almost automatic in its machinery.

39. What proportion of the produce sold in the market is raised within 25 miles of the market place?

Baltimore: Perhaps all, except choice and early fruits and vegetables shipped to the city in refrigerator cars from California and the South. Cincinnati: Except meats, perishable stuffs as oranges, etc., all of it is raised within 25 miles of Cincinnati. New Orleans: All of it, if you include cows slaughtered in the city. San Antonio: Almost the entire amount. Seattle: All excepting peaches, some of the apples and potatoes. Norfolk: About 50 per cent. Boston: The larger part of the produce brought daily by farmers comes within a radius of 30 miles; but large quantities are received by railroads and boats from the South, West and foreign countries. It is claimed that 95 per 
cent of the dressed meat coming to Boston comes from the West. Montreal: Cabbages, turnips and carrots, about 45 per cent; poultry, potatoes, etc., about 33 per cent. Rochester: Nine-tenths. Columbus: About three-quarters of the produce, vegetables and poultry. Dubuque: probably 95 per cent.

40. If you were establishing a market in your city what are some of the most important features you would avoid?

Baltimore: The present antiquated structures; the present system of revenue. New Orleans: Dirt and flies. San Antonio: Mid-day closing. Market should be open from 5 p.m. until 7.30 p.m. High rents avoid having anything sold in market except meats, fish, oysters, products of the farm, gardens and dairy. Seattle: The sale of anything except that which is grown by the man selling. This cuts out second hand dealers and commission men and keeps the matter substantially in the hands of farmer and truck men. Norfolk: Avoid anything which would in any way interfere with its free use by all citizens desiring to do so. It should be within easy reach of the residence section; should be kept in a cleanly and sanitary condition as not to be objectionable to any one. Montreal: See 33. Columbus: Varying conditions in every locality. Dubuque: Too much regulation, except as to sanitary matters and safeguarding against dishonesty.

41. What is the attitude towards the market of the truck-raiser and farmer in the territory adjacent to your city? Does he take advantage of the opportunity to sell direct to the consumer?

Baltimore: Favorable attitude. Takes advantage of opportunity Cincinnati: Hedoes. New Orleans: Yes. San Antonio: Yes. Seattle: Yes: Norfolk: Favorable, as it gives him an opportunity to compare prices obtainable here with prices he could obtain by shipping his produce to the eastern markets. Not to any considerable extent. Boston: Has the most friendly feeling; very little of his produce is sold direct to the consumer, although he may do so if he desire; he prefers to sell his load and go home for more supplies. Montreal: Yes. Rochester: Yes, all he can. Indianapolis: He can if he wishes. Many do. Columhus: As a general rule, yes. Some sell wholesale as their time is worth more on the farm than the difference in price would amount to. Dubuque: He makes a most extensive use of the market. It safeguards him against combinations of grocers, commission men and extortions of transportation companies, and always gives him an opportunity of getting some "spot" cash.

42. Has the establishment of a public market in your city encouraged an increase in the production of vegetables and other articles of food in the adjacent territory?

Baltimore: Our markets were established before incorporation of the city and have grown up with the city. The production of vegetables, etc., is en- 
couraged by the markets. Cincinnati: Yes. New Orleans: Not to any great extent. San Antonio: Yes. Seattle: Yes, decidedly so. Norfolk: Possibly it has, but it should be borne in mind that the local market does not take 1 per cent of the truck raised in this vicinity, which is one of the greatest truck raising sections in the country. The soil will produce about 125 barrels of spinach, per acre, and the amount of produce raised is enormous. For instance, one trucker raised 20,000 barrels of potatoes in one season. Boston: There are practically the same number of farmers bringing produce to the market for several years. Montreal: Yes. Rochester: Yes. Columbus: Yes. Dubuque: It has. Not only the city is supplied but much is shipped from here.

43. Is the number of produce growers in the territory within easy access of your market increasing or decreasing? What is the reason for the increase or decrease?

Baltimore: Cannot answer with certainty, but do not think decreasing. Cincinnati: Slowly increasing. New Orleans: No marked increase. San Antonio: Increasing. Demand increasing. Seattle: Yes, decidedly so. Norfolk: Increasing but the local market has very little to do with this result for the reason that it takes so small a proportion of what is raised. The reason the number is increasing is the fact that those engaged in truck raising have made a great success owing to the favorable conditions of elimate, soil, etc., and it is this success that has attracted others. Boston: See above. Montreal: The decrease in the mentioned territory is due to the fact that the farmers and gardeners, adjacent to the city, have sold their farms to be converted into building lots. Rochester: Increasing on account of increase of population. Columbus: Increasing for the reason that it pays to raise garden truck. Dubuque: It is increasing. The fathers and grandfathers have become rich at the business. The descendants naturally take to the profitable business, and quite a few broken-down city men, willing to labor, take to this as a last resort. 